\title{
Editor's Note
}

Happy New Year! C новым годом! Greetings and welcome to this first issue of SPSR for 2022. This issue contains the second half of the special issue that began in SPSR 48.3 (2021). As promised, our usual offering of book reviews returns in this issue as well. In addition, please be on the lookout for the return of standalone articles in the journal's second issue of 2022.

Concluding in this issue, the aforementioned special issue is entitled "Studies of the Siberian Anthropocene." Edited by SPSR Editorial Board member Dr. Andy Bruno of Northern Illinois University (DeKalb, United States), the second half of this special issue includes three articles by scholars from the Russian Federation.

I invite you to enjoy this latest issue of $S P S R$ as we look forward to this new year.

Christopher J. Ward

Editor-in-Chief 